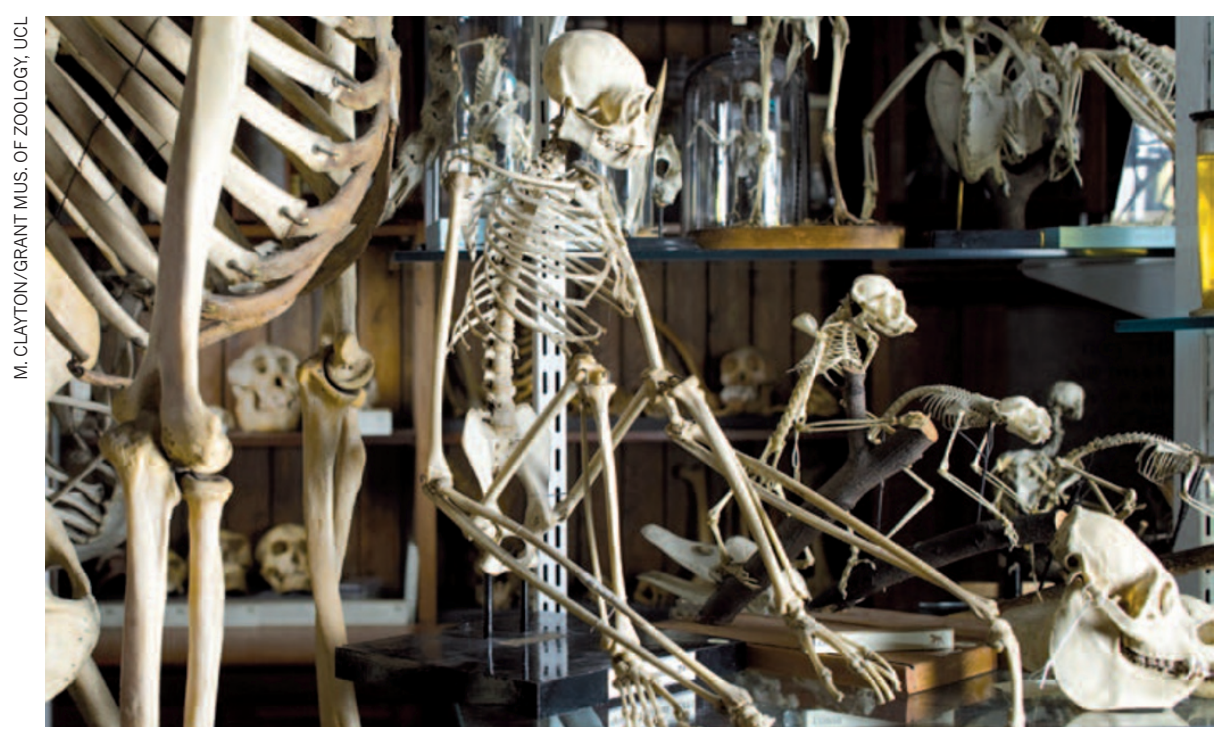

University College London's Grant Museum reopens this week in a new home with more space for specimens.

MUSEUMS

\section{Campus treasures}

\section{Sally MacDonald and Jack Ashby explain how best to air the gems hidden within university science collections.}

$\mathrm{U}$ niversity museums contain some of the richest and most extraordinary collections in the world, from Charles Darwin's Galapagos finches at the University of Cambridge, UK, to Louis Agassiz's vertebrate palaeontology specimens at Harvard University in Massachusetts. Such collections can draw on excellent resources - academic minds, vast libraries and student enthusiasm. But now that universities are increasingly required to demonstrate their impact on society, their museums must also claim a new role as vital public spaces.

Aiming to do just that, the Grant Museum of Zoology at University College London (UCL) reopens to the public this week after an eight-month closure while it moved to a new building. With the extra space in its new home, as its directors we intend to make it a vibrant place for experiment and dialogue by offering provocative, interactive and regularly changing displays. The museum retains its Victorian cabinets, crammed with skeletons and specimens in jars, with many coming out of storage for the first time - including dozens of primate and carnivore skeletons, newly rediscovered dodo material and a rare pterosaur fossil. But we will also pilot new ways of engaging visitors with science and scientists.

There is a pressing need to review the purpose of university museums. In the nineteenth and early twentieth centuries, when many significant collections were founded, a museum was seen as an essential teaching
Grant Museum of

Zoology

Rockefeller Building,

University College

London, UK.

Opens 15 March 2011.

resource for disciplines ranging from archaeology to zoology. The Grant Museum, for example, was set up in 1827 to house the growing collection of Robert Edmond Grant, who held the first chair in zoology and comparative anatomy at UCL. It has one of only seven known quagga skeletons (the extinct South African zebra, considered the rarest skeleton in the world) and a singular adult fluid-preserved specimen of a thylacine, or Tasmanian tiger, which was dissected by Thomas Huxley.

The Grant Museum has been well maintained, but many other university collections are in a parlous state - uncurated and unused, consigned to cramped basements or, on occasion, to the bin. Poor advocacy of their role within their parent institution (or beyond) is one reason for the lack of funding. Pressure on space is another: campus museums must compete with income-generating research facilities and student amenities. And whereas disciplines such as archaeology and art history use collections extensively, others, including the life sciences, have turned to digital resources instead of the real things.

Natural history collections have been particularly affected by this change in academic fashions, with the result that most science-engagement funding has flowed into science centres - concept-driven and specimen-free. With the financial situation now bleaker than ever, university museums must again reconnect with research and teaching and open their doors to the public.

Some university museums have already become major science-engagement venues for their cities. The Grant Museum first opened to the public in 1996, and offers a lively natural history learning programme, including lectures, film nights, debates and treasure hunts. The Peabody Museum of Natural History at Yale University in New Haven, Connecticut, which holds around 11 million objects ranging from meteorites and insects to scientific instruments, runs many public workshops. The 30 million objects, including thousands of type specimens, at the Humboldt University Museum of Natural History in Berlin are used in hands-on workshops and changing exhibitions.

\section{RESEARCH RELEVANT}

To remain relevant to teaching and research, the potential of historic collections needs continual reassessment. Although teaching in the life sciences has shifted away from whole organisms to a more molecular focus, natural history collections provide historical snapshots of past biodiversity. Biologists can analyse skeletal material, using new technologies such as three-dimensional scanners. Fossils and modern specimens are accessible to DNA analysis for studies in phylogenetics, population dynamics and conservation biology. At the Grant Museum, genetic samples have been used to date the extinction of the giant Irish elk, Megaloceros giganteus.

Successful university museums must promote themselves to academics and students from a wide range of disciplines. The Grant Museum provides object-based classes that go far beyond biology. We support teaching in arts management, archaeology, architecture, museum studies and even the performing arts - dance students from the Royal Academy of Dramatic Art use the museum to learn the anatomical basis of animal movement so that they can recreate it. Specimen-based modules run on the university's virtual-learning environment, allowing instantaneous feedback on students' coursework and enhancing their observational skills. The collection database has been available online since 2008 .

There are legal and ethical challenges to working with old collections in the public domain. No nineteenth-century assemblage of primates was complete without a human, but the storage and use of human remains is now tightly regulated; in Britain, no human material less than 100 years old can be displayed or used in teaching without an expensive licence. Uncertainties $\rightarrow$ NATURE.COM For a Q\&A with museum designer Edwin Schlossberg: go.nature.com/zzu2nc 
about acquisition dates raise the question of whether museums should risk displaying such remains, or use replicas instead. We have repatriated human remains to communities in Australia and New Zealand and are in the process of transferring all unprovenanced remains to a licensed teaching collection.

The display of specimens of endangered species also raises problems. The Convention on International Trade in Endangered Species restricts the commercial use of such material, and this includes their use in museums or one-off events for which admission is charged, or the featuring of listed animals in filming. We must carefully consider which specimens are used for such events.

We hope that the Grant Museum will become a space where the public, students and academics alike can use objects to tackle big questions in the life sciences and engage with the way museums work. Interactive labels, accessed on iPads located next to the exhibits, pose provocative questions, such as whether animal and human remains should be treated any differently. Visitors can respond using the iPads or smartphones, Twitter or home computers. Questions may be crowd-sourced in future, opening up the potential for the public to curate museum displays.

Like our much larger cousins, London's Natural History Museum or the American Museum of Natural History in New York, the Grant Museum is a working institution, where the collections are accessed constantly and real science is done. University research will be showcased by encouraging artists and scientists to co-curate designated cases or art installations using the collections. And discussions, teaching and debates will take place in a space in the centre of the displays. The museum staff will also be accessible so that visitors can ask questions.

The redisplay of the Grant Museum had to be done quickly and cheaply in comparison to typical museum redisplays: UCL footed the $£ 326,000$ (US $\$ 530,000$ ) bill. This imposed constraints but also brought benefits: no need to satisfy external funders, no problem with last-minute changes. This museum-cum-lab is a work in progress and we will no doubt struggle with stretched budgets. But if we can continue to find new ways to engage researchers, students and visitors with the collections, the Grant Museum should continue to evolve and thrive, at 184 years old and counting. -

Sally MacDonald is director of UCL museums, collections and public engagement at University College London, Gower Street, London WC1E 6BT, UK. e-mail:tcrnsmd@ucl.ac.uk Jack Ashby is head of learning and access at the Grant Museum of Zoology, University College London, UK.

e-mail:j.ashby@ucl.ac.uk

\section{Books in brief}

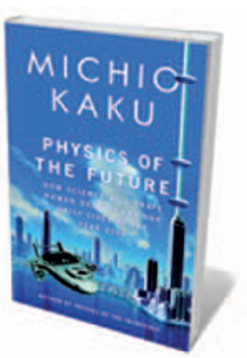

Physics of the Future: How Science Will Shape Human Destiny and Our Daily Lives by the Year $\mathbf{2 1 0 0}$

Michio Kaku DouBLEDAY 416 pp. \$28.95 (2011)

What will the world be like in the year 2100 ? Full of new life forms, emotional robots and antimatter rockets, according to string theorist and author Michio Kaku. Limiting himself to extensions of current technology, he synthesizes the ideas of 300 experts in diverse fields from neuroscience to nanotechnology. Whereas researchers expect predictions such as limitless computing and synthetic organisms to be fulfilled, others, such as prolific space travel, will be harder to pull off.

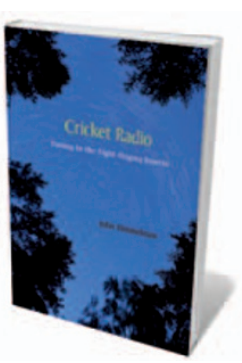

Cricket Radio: Tuning In the Night-Singing Insects

John Himmelman BELKNAP PRESS 272 pp. \$22.95 (2011)

Warm summer nights resonate with the chirruping of crickets and other night-singing insects. Amateur naturalist and writer John Himmelman seeks to reconnect us to these often-unseen musical creatures by mingling tales of his own searches for grasshoppers, cicadas and katydids with the latest professional research investigating why and how they sing, to attract mates and ward off predators. Himmelman collects the sounds of cricket calls on a website that accompanies the book (see go.nature.com/czodcg).

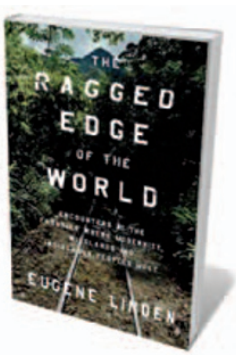

The Ragged Edge of the World: Encounters at the Frontier Where Modernity, Wildlands, and Indigenous Peoples Meet

Eugene Linden VIKING 272 pp. \$26.95 (2011)

In 40 years of reporting, environmental journalist Eugene Linden has witnessed great changes to swathes of the globe. Dense forests in New Guinea and Borneo have been opened up for timber and minerals; tourism has invaded remote areas such as Machu Picchu in Peru and the Antarctic. Linden calls for the expansion of ecological corridors and 'peace parks' to help species adapt to globalization and combat exploitation of the environment by the increasing human population.

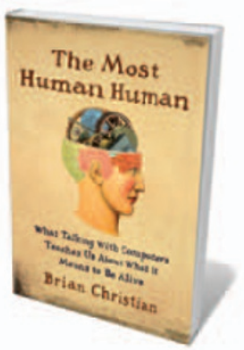

The Most Human Human: What Talking with Computers Teaches Us About What It Means to Be Alive

Brian Christian DOUBLEDAY 320 pp. \$27.95 (2011)

When it comes to good conversation, humans are usually better than a machine. Why artificial intelligence so often fails to live up to our emotional expectations, and what that tells us about being human, is the focus of science writer and poet Brian Christian's book. He relates what it was like to take part in a Turing test, which pitted him against a computer in an anonymous chat with a thirdparty judge in 2009, and the lengths to which he went to make sure that a human won.

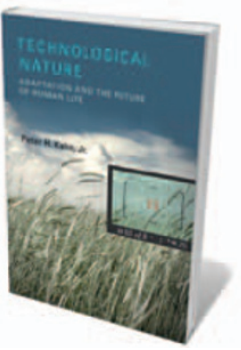

Technological Nature: Adaptation and the Future of Human Life Peter H. Kahn MIT PRESS 240 pp. \$24.95 (2011)

From watching wildlife documentaries to stalking animals with video cameras, we increasingly interact with nature through technology. After studying people's responses to real-time broadcasts of natural scenes and their play with robotic pets, psychologist Peter Kahn concludes that exposure to digital nature is better than having no natural experience at all. But, he finds, you cannot beat the real thing, arguing that we should view this 'technological nature' as a bonus rather than as a substitute for tangible natural wonders. 